\title{
Civic Education and Interest Group Formation in the American Law School
}

\author{
Jonathan R. Macey*
}

\section{INTRODUCTION}

Throughout history there have been two radically different approaches to civic education. Under one approach, which I will call the "rights-oriented" conception of civic education, citizenship is granted to certain people as a matter of right. In societies that use the rights-oriented approach, civic education may be viewed as a useful mechanism for improving the quality of the society. But it is not a prerequisite to citizenship. By contrast, under the alternative approach, which might best be described as the "gate-keeper" approach to citizenship, only those who meet certain qualifications are permitted to enter the community of citizens. Under this approach, the responsibilities of citizenship are such that only those able to show that they satisfy certain criteria, such as literacy or residency requirements, will be allowed to assume them.

Entrance into the community of lawyers, of course, is determined by the gate-keeper approach. As long as this is the case, it is inevitable that law schools will provide their students with a form of civic education. Thus, before considering whether American law schools should attempt to educate their students to be better citizens, it would seem logical to explore the kind of civic education that students already receive. By examining the kind of civic education currently offered at American law schools, one can get a good idea of what sorts of changes are possible. This paper attempts to demonstrate the pervasive nature of civic education in American law schools. During this process of civic education, law students become aware of one overarching reality. This reality, possibly the ultimate lesson they assimilate, is that their future prosperity is inextricably tied to the fate of the legal profession as a whole. As the legal profession prospers, so too will they. Indeed, the contractions in the legal profession during the late 1980s showed that continuing expansion of society's demand for lawyers is essential to the future well-being of law students.

The peculiar form of civic education that pervades the American law school can be explained by the law's classification as a "profession." Some

* J. DuPratt White Professor of Law, Cornell University Law School. Earlier versions of this article were presented at a faculty seminar at Cardozo Law School and at the Stonford Law Review Symposium on Civic and Legal Education. I am grateful for the comments received at those events, as well as for discussions with Linda R. Hirshman and Geoffrey P. Miller. 
would even elevate the practice of law to a "calling." 1 This professional classification of law justifies the maintenance of a "gate-keeper" membership approach. It is widely understood that in order to become a "professional," one must qualify. As Professor Charles Wolfram has observed, the qualifications for professional certification include an extended period of education, training or apprenticeship prior to engaging in the profession, and an examination by persons who already hold the designation "lawyer."2 Above all, members of a profession have demonstrated a willingness to accept rigid control of the established hierarchy within the profession:

Often the control is exerted in the form of a code of ethics. Relative isolation from the surrounding community and intense self-regulation lend the profession a sharply defined membership, purpose, and reason for being. Regulatory control almost always extends to creating and enforcing standards of admission and exclusion and defining the qualifications of competence and character required of a professional in good standing. ${ }^{3}$

This essay first examines the ways in which the civic education delivered in law school inevitably aligns the interests of the law student with those of the profession. The decision to enter law school is a decision to develop a particular set of professional skills. These skills constitute a nondiversifiable investment in human capital. Thus, law students develop a sizeable vested interest in maintaining the value of the education they receive. As a student progresses through law school and begins her career, this investment not only increases in size, it also becomes more specialized in nature. The student develops fairly generic research and analytic skills early in law school, and more specialized skills later on. Upon graduating, specialization becomes even more pronounced when the student takes a state bar examination, which focuses her practice on a single jurisdiction. Then, while developing her legal practice, the lawyer generally develops extremely specialized legal skills.

In Part II, I argue that this process of making increasingly specialized human capital investments during law school constitutes a powerful form of civic education. Because law students view their own welfare as inextricably linked to the welfare of the legal profession, they come to view changes in societal and legal norms that could harm the legal profession as harmful to themselves, and changes potentially beneficial to the legal profession as beneficial to themselves.

Thus, legal training necessarily alters the preferences of the people who receive it. The graduates of a given law school are a less diverse group than they were three years earlier because law school has altered the nature of their preferences. This assertion will be supported with specific examples

1. Roscoe Pound, The Lawyer from ANTiQuity to Modern Times 5 (1953); cf. Ellis v. Frawley, 165 Wis. 381, 383, 161 N.W. 364, 366 (1917) (stating that the "practice of law is not a trade but a ministry").

2. Charles W. Wolfram, Modern Legal Ethics 14-15 (1986).

3. Id. at 15 . 
from such law school courses as professional responsibility, constitutional law, and securities regulation.

In Part III, I describe some of the costs of this process of civic education. For example, people who have had the benefits of a legal education are likely to discount the cost of complexity and the value of certainty in a legal system. Similarly, but more generally, lawyers are likely to see only the benefits, but none of the drawbacks, of constructing a society in which they play a dominant role in virtually every facet of life.

Finally, Part IV discusses how legal education might be reformed to deal with some of the problems posed by the peculiar sort of civic education provided in the American law school. In particular, I argue that interdisciplinary studies offer the best hope for mitigating the interest-group capture of the American law student.

\section{Law School as a Human Capital Investment}

For economists, the term "capital" describes those things used to produce goods and services. Economists distinguish among the huge array of various capital investments the market generates in two important ways. First is the distinction between physical capital (buildings, machinery, and other manufactured items) and human capital (the knowledge and skills that people develop through education and training). Obviously, the investment made to become a lawyer is in human capital. The second distinction among types of economic capital important for the purposes of this essay is between those investments that are "general" and those that are "specific."

A general capital investment can be put to a wide variety of uses, while a specific capital investment has a specialized function. For example, reading and typing are general skills that can be used in a wide range of economic activities. By contrast, a cab driver's detailed knowledge of the back routes between mid-town Manhattan and LaGuardia airport, or a litigator's familiarity with the intricacies of Iowa's rules of evidence, cannot be readily transferred to alternative uses.

Thus, specific capital investments are assets so customized to a particular use that their value in an alternative use is greatly diminished. The investment that college graduates begin to make when they matriculate to law school can best be described as a specific investment in their own human capital. This investment is extremely risky. The risk associated with it cannot effectively be reduced through diversification. While investors in certain assets, such as stocks, can reduce the risks associated with those investments by holding diversified portfolios, investors in human capital find diversification far more difficult. Further, the specific nature of lawyers' investment in obtaining a license to practice law subjects them to exploitation. Imagine a litigator at a large corporate law firm who makes $\$ 250,000$ a year defending corporate clients in shareholder derivative suits. Now suppose that all fifty states amend their corporate laws to deprive shareholders of the right to 
bring derivative suits on behalf of the firms in which they have invested. ${ }^{4}$ This litigator is no longer able to practice in his specialty and must strike out on his own. In all likelihood, the compensation that this lawyer can command in his next highest alternative use will be substantially lower than his current compensation.

Perhaps the best example of the highly specific nature of much of the education provided by law school concerns the specialized legal language that students begin to absorb when they commence their legal training. Law students also begin to obtain detailed information about the structure of the legal profession and the court system, as well as the process of legal research. Locating statutes, court decisions, and administrative materials involves an investment in specific knowledge, as does the effort involved in learning how to write a brief, a complaint, or a legal opinion letter (all skills taught during the first year of law school). Similarly, courses like civil procedure, property, criminal procedure, administrative law, and conflict of laws contain material that is of little, if any, use to people who are not actively involved in the practice of law.

Virtually every American law school has adopted, to some degree or other, the model of legal education established by Christopher Columbus Langdell during his twenty-four year deanship of Harvard Law School in the last quarter of the nineteenth century. The primary feature of this model is the study of law in large classes, in which the learning materials consist chiefly of edited appellate cases, taught through a process of professorial questioning euphemistically described as the case-method. Under this socalled "Harvard" model of legal education, the emphasis is "not upon mastering the welter of detail involved in the cases or in law generally, but in a process of critical and creative thinking that was thought to typify the work of the best lawyers."s In other words, the primary task of the American law school is to teach students to think like lawyers.

There has been considerable debate about precisely what it means to "think like a lawyer." Perhaps the best description of the skill that is taught in the typical law school classroom is Professor Anthony Kronman's:

Today, as sixty years ago, the most important skill the law teacher imparts is the skill of advocacy, the ability to construct and defend a convincing legal argument. Before the law student can find any other analytic techniques professionally useful, he must have mastered the ability to make a legal argument-he must know how to build an argument from legal materials, such as cases, statutes, administrative orders, and the provisions of the Constitution, in accordance with the established, if not always precise, rules that determine how these materials are to be used, such as the rule of stare decisis coupled with the techniques for construing a judicial opinion in either an expansive or restrictive way. The other techniques taught in law school can

4. For an extended discussion of the interests of the corporate bar, see Jonathan R. Macey \& Geoffrey P. Miller, Toward an Interest-Group Theory of Delaware Corporate Law, 65 TEX. L. REv. 469 (1987).

5. Wolfram, supra note 2, at 195. 
supplement this most basic skill, but despite the enormous curricular changes of the last sixty years, the skill of advocacy remains the cornerstone of all law-school instruction. ${ }^{6}$

Put another way, the skill taught in law school is what Plato Socratically described as "the power to persuade by speech jurymen in the jury-court, council-men in the Council Chamber, assembly-men in the Assembly, and in every other gathering, whatever political gathering there may be."7 As Professor Kronman insightfully has observed, Socrates' point was that "the defining goal of legal advocacy is ... the production of conviction rather than knowledge."8 Kronman adds, somewhat more controversially, that the defining characteristic of the training that one receives in law school is the development of what is alternatively described as an "indifference"9 or a "cynical carelessness" about the truth. ${ }^{10}$

The skills of advocacy that one learns in law school are fundamentally different from the skills one learns as an accountant or an engineer. Because of the specialized nature of the skills taught in law school, the risks associated with becoming a lawyer differ significantly from the risks associated with entering other professions such as medicine or engineering. Clearly the return on investments in these other professions can be affected by exogenous shocks, but there is an international market for professionals like engineers, accountants, and even doctors. Such a market cannot exist for lawyers because of the fact that the demand for lawyers' services is tied inextricably to lawyers' specialized knowledge of particular national legal systems. ${ }^{11}$

The point here is simply to debunk the old myth that there are few, if any, risks associated with becoming a lawyer. In fact, because the professional training required to become a lawyer involves a specific, nondiversifiable human capital investment, there are substantial risks associated with legal training. In particular, any exogenous circumstance that reduces society's demand for legal services would greatly reduce the income of lawyers as a group.

While it is impossible to predict with certainty how far lawyers' earnings would decline as a result of changes that reduced the demand for lawyers, a recent analysis of data from the Current Population Survey showed that lawyers command a 63 percent premium in annual earnings compared with the average earnings of all American college graduates. ${ }^{12}$ This translates into a return of more than 16 percent for each year of law school.

The implications of the above analysis should be clear: Over the course

6. Anthony T. Kronman, Foreword: Legal Scholarship and Moral Education, 90 YALE L.J. 955, 959 (1981).

7. Plato, Gorgias 19 (Terence Irwin trans., 1979).

8. Kronman, supra note 6, at 963.

9. Id. at 965 .

10. Id. at 967.

11. Even international lawyers must have knowledge of national law in order to enforce judgments obtained in international tribunals.

12. Sherwin Rosen, The Market for Lawyers, 35 J.L. \& Econ. 215, 217-18 (1992). 
of a three year legal education, an important transformation takes place. Before entering law school, a student's future income is wholly unrelated to the welfare of the legal profession as a whole. By the end of law school, much of the value of the substantial investment made in obtaining a legal education depends on the future of the profession.

The point made here is not one of ideology. These arguments would be no less valid if law schools did not alter students' ideologies at all. Indeed, students who enter law schools with left-leaning political views are likely to remain on the left, and students who enter with right-wing views are likely to retain those views. However, while in law school, students of all ideological persuasions discover a new mechanism-the law-for expressing their views and accomplishing desired policy objectives. It is extremely rare for a law student of any political stripe even to consider exploring an avenue outside the law as a means for accomplishing change. This fact alone demonstrates the awesome effectiveness of the preference transformation that occurs in law school.

In a nutshell, then, students enter law school to become lawyers. By the time they are ready to graduate, they have become members of a powerful distributional coalition. But the preference formation that occurs in law school is not exclusively a result of the economic interests of law students. It is an elementary tenet of social psychology that our choice of vocational role has a strong influence on our attitudes and values. ${ }^{13}$ Our tendency to internalize our vocational roles substantially influences our attitudes and personalities. ${ }^{14}$ For example, an important study comparing the attitudes of industrial workers who were promoted to management positions with the attitudes of industrial workers who were promoted to union positions demonstrated that the workers in management positions became more sympathetic to management's positions, while the workers in union positions became more closely aligned with the union's views. ${ }^{15}$

Much of law school requires law students to place themselves in the role of attorneys for various purposes. Indeed, the traditional Socratic method employed in the law school classroom places the professor in the role of judge and the students in the role of lawyers. Successful students are those who can spot issues or concoct arguments that have been missed by the lawyers in the appellate cases being studied. It stands to reason that the law students who play these roles internalize some of the values of the people and institutions they are imitating.

Similarly, the theory of escalating commitments also suggests that law

13. David G. MYers, Social Psychology 46-47 (1983); Jerald G. Bachman \& Patrick M. O'Malley, Self-Esteem in Young Men: A Longitudinal Analysis of the Impact of Educational and Occupational Attainment, 35 J. Personality \& Soc. PsYchol. 365, 377 (1977).

14. MYERS, supra note 13 , at $46-47$.

15. Seymour Lieberman, The Effects of Changes in Roles on the Attitudes of Role Occupants, 9 HUM. REL. 385 (1956). 
students will come to identify strongly with the legal profession. ${ }^{16}$ An initial decision made and defended is likely to affect future decisions such that those decisions will comport with the earlier actions. For example, studies of the decision making process that contributed to the escalation of the Vietnam War showed that leaders often paid more attention to new information that was compatible with their earlier decision to make a military commitment in Southeast Asia. They tended to ignore information that contradicted those earlier assumptions. As one researcher noted, "[t]here was a tendency, when actions were out of line with ideas, for decision-makers to align their ideas with their actions."17 Once these ideas and beliefs become ingrained, whether through role-playing or escalating commitments, the possibility of altering these beliefs decreases substantially. One psychologist has argued that "beliefs are like possessions." 18 Expanding on this theory, another social psychologist explains that "[w]e acquire and retain material possessions because of the functions they serve and the value they offer. To some extent, the same can be said of our beliefs: We may be particularly inclined to acquire and retain beliefs that make us feel good."19 While this theory can easily justify the actions of our leaders in the Vietnam crisis, who needed psychological reinforcement to the effect that they were pursuing correct policy objectives, it can also be applied to the civic education provided in law school. We have seen that once law students begin to identify with the legal profession, they recognize the degree to which their personal welfare follows the welfare of the whole profession. As the student comes to identify with the legal profession, he or she will tend to discount arguments that contradict the assertion that lawyers serve societal needs. ${ }^{20}$ As Professor Thomas Gilovich has noted, "we are quite possessive and protective of our beliefs, as we are of our material possessions. When someone challenges our beliefs, it is as if someone criticized our possessions."21 Once a law student believes strongly in the social value of lawyers, he or she will develop a

16. The theory of escalating commitments is described in MYERS, supra note 13 at 287-91, and Robert P. Abelson, Beliefs are Like Possessions, 16 J. FOR THEORY SOC. BEHAv. 223, 239-40 (1986).

17. Ralph K. White, Selective Inattention, PsYCHOL. TODAY, Nov. 1971, at 47, 82.

18. Abelson, supra note 16 , at 223.

19. Thomas Gilovich, How We Know What ISN'T So: The Fallibility of Human REASON IN EVERYDAY LIFE 86 (1992).

20. Indeed, social psychologists have observed that people are more likely to believe things that they want to believe, but that this syndrome

is constrained by objective evidence and by their ability "... to construct a justification of their desired conclusion that would persuade a dispassionate observer. They draw the desired conclusion only if they can muster up the evidence necessary to support it." It is informative in this respect that people generally think of themselves as objective. People rarely think that they hold a particular belief simply because they want to hold it, the evidence be damned. This sense of evidence can nevertheless be illusory: Although people consider their beliefs to be closely tied to relevant evidence, they are generally unaware that the same evidence could be looked at differently, or that there is other, equally pertinent evidence to consider.

Id. at 80 (quoting Ziva Kunda, The Case for Motivated Reasoning, 108 Psychol. BuLL. 480, 482-83 (1990)) (footnotes omitted).

21. Id. at 86 . 
distorted perspective on the costs and benefits of our litigious society, diminishing the possibilities for desirable reform.

Finally, empirical research in social psychology demonstrates that the mere act of role playing that occurs in law school can alter students' preferences. ${ }^{22}$ Social psychologists refer to this as the phenomenon of "saying is believing." 23 Perhaps the most powerful example of this process in action is contained in Patricia Hearst's explanation of how she ultimately came to share the views of the members of the Symbionese Liberation Army (SLA) who had kidnapped her: "I had thought I was humoring (the SLA) by parroting their cliches and buzz words without personally believing in them ...." "24 However, she later realized that " [i]n trying to convince them I convinced myself." "25

Professor Raymond Hyman provides a fascinating description of how, by acting in the role of a psychic, he convinced himself that he had psychic powers:

I started reading palms when I was in my teens as a way to supplement my income from doing magic and mental shows. When I started I did not believe in palmistry. But I knew that to "sell" it I had to act as if I did. After a few years I became a firm believer in palmistry. One day the late Dr. Stanley Jaks, who was a professional mentalist and a man I respected, tactfully suggested that it would make an interesting experiment if I deliberately gave readings opposite to what the lines indicated. I tried this out with a few clients. To my surprise and horror my readings were just as successful as ever. Ever since then $I$ have been interested in the powerful forces that convince us . . that something is so when it really isn't. ${ }^{26}$

In other words, the ritual of a legal education, particularly the continuous pattern of verbal commitment from students through class participation in the Socratic question-and-answer system prevalent at most law schools, causes law students gradually and subtly to change their attitudes and preferences toward the legal system. This process is, of course, greatly reinforced by an educational system that rewards those students best able to provide the "right" answers on examinations with high grades and other honors.

In sum, then, individuals have a strong tendency to find justifications for their own actions and behavior. Those who choose to participate in the educational process at law school generally will find a way to justify those decisions. Generally speaking, one cannot possibly justify the decision to attend law school if one thinks that the activities of most lawyers are without societal value. Thus, most attorneys, regardless of wide divergences in their ideological beliefs on other issues, believe that lawyers' work serves society.

22. See Ellen Tobey Klass, Psychological Effects of Immoral Actions: The Experimental Evidence, 85 PsYchol. Bull. 756 (1978).

23. MYERS, supra note 13, at 50.

24. Id. (quoting Patricia Hearst).

25. Id.

26. Ray Hyman, Cold Reading: How to Convince Strangers That You Know All About Them, in Paranormal Borderlands of SCIENCE 79, 86 (Kendrick Frazier ed., 1981). 
Plaintiffs' attorneys think that litigation serves societal interests by deterring negligent conduct. And corporate lawyers believe that expanding the role of lawyers in the corporate decision making process benefits society by improving the quality of corporate governance.

Social psychologists have studied a similar phenomenon across different vocations and have concluded that people have the tendency to believe what they want to believe. As Professor Gilovich recently has written:

[M]ost of the evidence indicating that people tend to believe what they want to believe comes from research on people's assessments of their own abilities, and their explanations for their own actions. One of the most documented findings in psychology is that the average person purports to believe extremely flattering things about him or herself-beliefs that do not stand up to objective analysis. We tend to believe that we possess a host of socially desirable characteristics, and that we are free of most of those that are socially undesirable. For example, a large majority of the general public thinks that they are more intelligent, more fair minded, less prejudiced, and more skilled behind the wheel of an automobile than the average person. This phenomenon is so reliable and ubiquitous that it has come to be known as the "Lake Wobegon effect," after Garrison Keillor's fictional community where "the women are strong, the men are good-looking, and all the children are above average." 27

Indeed, the ability of lawyers to justify what they do on the grounds that it provides general benefits to society is nothing short of remarkable. As I have noted in another context, even judges are likely to devise legal rules that increase the demand for lawyers. ${ }^{28}$ This tendency is not the result of any desire to promote their cronies within the legal profession. Rather, it results from an honest belief that the interests of justice are best served by expanding the role of lawyers in all sorts of decisions. For example, the best theory for explaining the peculiar contours of Delaware corporate law argues that those rules are designed to maximize the demand for Delaware corporate lawyers. Decisions by Delaware judges have been essential to the development of this body of law. These judges have not encouraged this trend because of a cynical interest in increasing the revenues of their former colleagues, but rather genuinely believe that lawyers are adding value to the economic system. ${ }^{29}$

Thus, whether one approaches the issue of legal education from an eco-

27. Gilovich, supra note 19, at 77 (citations omitted).

28. See Macey \& Miller, supra note 4, at 502 (observing that the Delaware judiciary is likely to favorably review legislation providing Delaware lawyers with a large role in corporate affairs).

29. Professor Miller and I have noted that in Delaware:

[W] ell-intentioned judges can be expected to devise legal rules requiring that Delaware lawyers be consulted when important decisions are to be made. Moreover, [because] Delaware judges believe that the state judicial system well serves Delaware corporations, they will be more likely to approve rules that stimulate litigation in the Delaware courts. Thus ... the Delaware judiciary is likely to approve rules that serve the interests of the corporate bar. This judicial temperament lowers the costs to the Delaware bar of achieving the legal Id. environment that maximizes demand for its services. 
nomic perspective or from the vantage point of social psychology, the same conclusion emerges. Lawyers will try to find ways to expand the demand for their services. They will do this not only because it is in their narrow selfinterest to do so, but also because they genuinely believe it is in society's interest for them to do so. This is simply another way of saying that during law school law students internalize the values of the legal profession. In so doing, law students come to believe that what is good for lawyers is good for society.

\section{LaW School as a Negative EXTERnality}

The preceding section depicts legal education as a forum in which law students make specific, nondiversifiable investments in human capital that come in the form of highly specialized training in the art of advocacy and persuasion. In the course of this educational process, students' preferences begin to change. Law students become wedded to the legal system because of their investment in it. They also become somewhat cavalier about the process of truth seeking, because truth seeking is not relevant to the process of lawyering. As Professor Kronman observes:

It is easy to believe that efforts to state the truth about man's moral and social life are illusory and vain; the professional attitude of the advocate, as it hardens into a habit, tends to confirm this belief and to augment its power.

To put the same point a slightly different way, when one practices advocacy in a self-conscious manner for a long time, the experience, like any extended experience of this sort, is likely to affect what one cares about. Our cares reflect our habits ... and the habitual indifference to truth that the advocate must cultivate in his professional life is likely to promote what is perhaps best understood, in a literal sense, as a kind of carelessness about the truth. Because one's character depends to a large degree on what one cares about, an education in advocacy tends to produce a character of a certain type. ${ }^{30}$

This is not meant as a wholesale condemnation either of the advocacy system in general or of the American system of legal education in particular. Indeed, a vigorous defense of the advocacy system can be made on the ground that it is uniquely capable of generating justice in an imperfect world. This defense, of course, is based on the reasonable assumption that each lawyer's presentation of alternative versions of reality will contribute to a process in which justice is served. Once again, Professor Kronman's contribution on this subject is worth noting:

[T] he practicing advocate may be confident that the truth will be revealed ... through a process in which competing advocates pit their skills of persuasion against one another, on behalf of clients in a courtroom or interests in a legislature. Nevertheless, it is not the advocate's goal, as an advocate, to bring the truth to light. If the truth is revealed, it is because activities of many advocates, each aiming at something fundamentally different, have

30. Kronman, supra note 6 , at 965 . 
been coordinated, like those of Adam Smith's baker and butcher, in such a way as to bring this result about by a kind of invisible-hand mechanism. Although the advocate may contribute to the discovery of the truth by participating in a process of this sort, he does not take its discovery as his own deliberate task. If his work brings the truth to light at all, it does so incidentally and not purposefully. Once again, we are brought back to the Socratic view: in doing what he does, the advocate is indifferent to truth. ${ }^{31}$

Professor Kronman's response to this dilemma was to place the law professor in the role of a moral educator-the law teacher is uniquely suited to this role because scholarship seeks knowledge and truth for their own sake. Consequently, Kronman believes that scholarship is an antidote to the indifference to truth that advocacy produces. But Kronman's endorsement of law teachers as moral educators has at least two flaws. First, his description of scholarship as preoccupied with the discovery of truth defines only a small fraction of the work product that masquerades as legal scholarship. While some legal writing, especially that with an emphasis on empirical data and social science methodology, might satisfy his description of truth seeking, much that passes for legal scholarship simply reflects the idiosyncratic preferences and ideologies of its authors. Exposing law students to this sort of scholarship simply reinforces the indifference to the truth that characterizes the rest of the advocacy training received in law school. For example, much legal scholarship argues for changes in the law, for expanding or contracting available remedies, or for creating new causes of action. Most of this work is based on the naked, wholly unsupported intuitive beliefs of the authors, rather than on any objective support, such as cost-benefit analysis or empirical testing.

The second problem with Professor Kronman's analysis is more fundamental. To the extent that law professors teach students how to engage in "pure" scholarship devoted to the discovery of truth, they diminish their students' ability to serve effectively as advocates. After all, an effective advocate is one who can slant the facts in his client's favor. A great advocate is one who internalizes and then espouses a version of the truth that casts the client's case in the most favorable light. The advocate's indifference to the truth is important to his ability to persuade because the advocate must persuade himself of the merit of his client's position before he can effectively persuade others of the same thing. ${ }^{32}$ As any criminal lawyer knows, a preoccupation with the truth can be quite harmful to a client's interests.

Thus, while Professor Kronman is right when he observes that teaching advocacy entails teaching cynicism about the truth, his argument that "law teachers have a moral responsibility to prevent this cynicism from taking root in the souls of their students"33 is more problematic. Because a certain

31. Id. at 963 .

32. Indeed, Professor Kronman himself clearly recognizes this fact. Id. at 961 (conceding that "[f]or powerful psychological reasons, the orator's need to persuade his listeners that these beliefs are true often makes it important that he persuade himself of the same thing").

33. Id. at 967. 
cynicism about the truth can make one a better lawyer, the clients of a student lacking such cynicism could be at a distinct disadvantage. Put differently, no law school can simultaneously inculcate its students with both a love for the truth and a skepticism about it; law students must choose between mastering the art of persuasion or mastering the science of truth seeking.

Professor Kronman's essay focuses on the responsibilities of law professors and on the ways they can achieve a better understanding of their vocation. But by focusing exclusively on the effects of pure scholarship on the moral educator, he does not consider the effects of such scholarship on legal training. At best, pure scholarship can provide advocates with tools that are useful in the art of persuasion. But a fundamental and irreconcilable chasm remains between the role played by the advocate and the role played by the scholar. Those who are truly devoted to pure scholarship are unlikely to be attracted to a life of advocacy. And those who love advocacy are likely to care more about their ability to convince their listeners than in their own, personal discovery of the truth.

Thus far, I have attempted to establish three related points about civic education in American law schools. First, law school represents a specialized investment in obtaining a specific set of professional skills. Second, this specialized investment causes law students to develop an economic and psychological stake in the legal system. Finally, perhaps the most distinctive feature of law school is the specialized training in advocacy, which places a higher premium on the ability to persuade than on the ability to discern the truth.

Taken together, these observations about law school lead to three conclusions. First, to the extent that civic education means educating lawyers to serve positive roles in society, it is likely that most law professors already believe that they are accomplishing this. Second, the education provided in American law schools causes lawyers to view the role of lawyers in society from a distorted perspective, which focuses far more on the benefits of legal representation than the costs. Finally, there is a basic, irreconcilable tension between the goals of the advocacy training received in American law schools and the goals of civic education.

\section{The Legal Process and the Public Good}

Most people believe that there are too many lawyers, too much litigation, and that lawyers themselves have too much power over public life. ${ }^{34} \mathrm{By}$ contrast, while many lawyers may believe that there are too many other lawyers, few would support meaningful reforms directed at reducing the demand for lawyers. The American Bar Association excoriated Vice President Dan Quayle for his remarks about the economic burdens caused by lawyers. ${ }^{35}$ Even the noble belief many lawyers hold that expanding legal ser-

34. See, e.g., Walter K. Olson, System Overload, A.B.A. J., Oct. 1991, at 70.

35. The full text of Vice President Quayle's speech to the ABA on August 13, 1991 can be 
vices to the poor is a good idea reflects their self-interest. These sentiments can be explained by the fact that the organized bar, like other interest groups, wants to increase the demand for its own services. But it also seems clear that lawyers genuinely believe that increasing the overall level of legal services in society will be beneficial. That is why lawyers view pro bono legal activities as a public good. ${ }^{36}$

Similarly, judges also devise legal solutions directed at expanding society's demand for lawyers. Perhaps the best example of this phenomenon is Smith v. Van Gorkom, ${ }^{37}$ known as the Trans Union case. In this decision, the Delaware Supreme Court shocked the corporate world by holding that a corporate board of directors had violated its fiduciary duty of care to shareholders and would be subject to massive personal liability for failing to exercise sufficient deliberation before approving a cash-out merger offer which would have given shareholders a 50 percent premium over the premerger market price for their securities. The court based its opinion on its belief that the Trans Union board of directors was grossly negligent for reaching a decision to recommend the merger without having constructed an appropriate procedural framework for the decisionmaking process. ${ }^{38}$ The court determined that the board's hasty decisionmaking process was per se actionable; it never even considered the possibility that the board might have decided that the costs of engaging in an involved, adjudicatory-style deliberation might outweigh the benefits. ${ }^{39}$ For example, such a deliberative process would be costly if it resulted in a delay that caused the bidder to withdraw its offered bid, thereby depriving the shareholders of the opportunity to obtain a substantial premium for their shares.

In sum, the court faulted the directors for not engaging a sufficient number of lawyers and investment bankers to produce a paper record justifying the transaction. The decision does not in any way curb the virtually unfettered freedom of corporate directors to accept or reject merger proposals. Rather, it makes clear that corporate boards of directors can do whatever they want, so long as they can establish that the appropriate procedural framework was erected and followed. As Professor Geoffrey Miller and I have observed:

found in Verbatim, Legal Times, Aug. 19, 1991, at 9. John J. Curtain, Jr., the outgoing President of the American Bar Association took the podium immediately following the Vice President's speech to chastise the Vice President for claiming he wanted to eliminate lawyers. See David Margolick, Address by Quayle on Justice Proposals Irks Bar Association, N.Y. TIMES, Aug. 14, 1991, at A1. Newly elected ABA President Talbot D'Alemberte described the Vice President's remarks as "patently absurd." Talbot "Sandy" D'Alemberte, Restarting Engine of Law Reform, A.B.A. J., Oct. 1991, at 8; see also Ray August, The Mythical Kingdom of Lawyers, A.B.A. J., Sept. 1992, at 72 (disputing Vice President Quayle's statistics).

36. See Letter from J. Michael McWilliams, President, American Bar Association, to Florida Supreme Court (Feb. 26, 1993) (on file with the Stanford Law Review).

37. 488 A.2d 858 (Del. 1985).

38. Id. at 881; see also Jonathan R. Macey \& Geoffrey P. Miller, Trans Union Reconsidered, 98 YALE L.J. 127, 134-35 (1988).

39. See Macey \& Miller, supra note 38, at 140-43 (discussing the cost of the Trans Union decision). 
[T] he remedy prescribed by Trans Union is far more than a nostrum. To be sure, the case will increase the use of investment bankers and lawyers in corporate decision-making. We agree with the proposition that in general the increased "papering" of board decisions will not substantially raise the level of deliberations. In this respect, the case appears as a boon to investment bankers and lawyers, but at a net cost for shareholders of Delaware corporations and for the nation's economy generally. ${ }^{40}$

Another case illustrating this phenomenon is Zapata Corp. v. Maldonado. ${ }^{41}$ In this case, which "provides more comfort to Delaware lawyers than to shareholders," 42 the Delaware Supreme Court established an elaborate two-step process for determining when an independent committee of a corporate board of directors could dismiss a shareholders' derivative lawsuit. The holding requires corporations "to spend large sums on information gathering [even] if these costs exceed the expected gain from better informed business decisions." 43 Since much of the information gathering required by this opinion will be conducted by or under the direction of lawyers, "[t]he beneficiaries of the decision . . . will be Delaware attorneys." 44

Similarly, in Moran v. Household International, Inc., ${ }^{45}$ the first judicial challenge in Delaware to the use of a poison pill rights plan as an antitakeover defense strategy, the court reached a decision that neither approved or disapproved the use of this antitakeover strategy. Instead, the court reached a result that left open the possibility of profitable litigation in every case in which a poison pill is employed. ${ }^{46}$ Finally, in Weinberger $v$. UOP, Inc., ${ }^{47}$ the Delaware Supreme Court made it clear that procedure will dominate over substance when Delaware courts are evaluating the fairness of the cash-out merger of a subsidiary corporation into its parent. ${ }^{48}$

Thus, Trans Union demonstrates the extent to which the values of the legal profession-which stress the virtues of advocacy and process over other values such as efficiency-are internalized by attorneys and judges. These values reflect the civic education provided sub silentio as an integral part of the education obtained in American law schools.

Even the most casual reference to the ethical guidelines that govern the behavior of lawyers supports the arguments made here. For example, New York's Code of Professional Responsibility makes the provision of legal serv-

40. Id. at 139.

41. 430 A.2d 779 (Del. 1981).

42. Macey \& Miller, supra note 4, at 516.

43. Daniel R. Fischel, The "Race to the Bottom" Revisited: Reflections on Recent Developments in Delaware's Corporation Law, 76 Nw. U. L. REv. 913, 940 (1982).

44. Macey \& Miller, supra note 4, at 517.

45. 500 A.2d 1346 (Del. 1985).

46. See Macey \& Miller, supra note 4, at 519-22.

47. 457 A.2d 701 (Del. 1983).

48. The court concluded that when defendants in such a transaction show disclosure of all relevant material facts, followed by approval by a majority of the minority shareholders, the burden "entirely shifts" to the plaintiffs to show the transaction was unfair as to them. Id. at 703. 
ices to the poor the responsibility of every lawyer. ${ }^{49}$ And rule 6.1 of the Model Rules of Professional Conduct provides that "[a] lawyer should render public interest legal services," 50 such as providing legal services to "persons of limited means ... at no fee or a reduced fee." ${ }^{21}$ It is noteworthy that the ethical requirement to help the poor cannot be satisfied by volunteering to do literacy training or work in a soup kitchen, despite the fact that these alternative forms of charity might do more to help the poor than the contribution of free legal services.

Similarly, it is well known that the first duty of any lawyer is to represent his client "zealously within the bounds of the law." 52 Thus, there is no room in legal ethics for examining the broader implications of a lawsuit, and precious little room for even a cost benefit analysis from the client's perspective. For example, suppose a lawyer believes that a particular litigation position is good for her client but bad for society generally. Her obligation to represent her client zealously means that society's interests must be ignored. Similarly, the duty of zealous representation does not leave room for a lawyer to cut costs during the course of her representation.

The deeply embedded assumption behind this rule is that lawyers are good and more lawyers are better. The results generated by the legal process itself determine whether justice is served by a particular set of legal rules. In other words, only by losing cases will lawyers and clients discover the social value of the cases they bring.

Prior to enrolling in law school, the focus of one's thinking about legal rules often centers on their ethical and moral characteristics. For the nonlawyer, issues like abortion, the death penalty, presentencing incarceration, mandatory busing, and gay marriage, are primarily, if not exclusively, informed by conceptions of individual or group rights.

The problem with law school is not that these conceptions of individual rights disappear. Rather, in law school these preconceptions of what is right and good are channelled so that discussions of rights and values are made in legal rather than moral terms. And while it may be true that "[w]e are all equally situated to make moral claims about the right and the good," 53 lawyers are uniquely well situated to make statements about what the law is. Moreover, lawyers are particularly well situated to manipulate the words and symbols of the law to assert or defend a particular moral position on legal grounds. These abilities give lawyers a unique power in society.

The point here is not to enter the venerable argument among legal philosophers about the difference between law and morality. Rather, the point

49. New York State Bar Association, The lawyer's Code of Professional ReSPONSIBILITY EC 2-25 (1978).

50. Model Rules of Professional Conduct Rule 6.1 (1990). This rule has been adopted in a majority of states. Roger C. Cramton, Mandatory Pro Bono, 19 Hofstra L. Rev. 1113, 1123 (1991).

51. Id.

52. LAWYER's CODE OF PROFESSIONAL RESPONSIBILITY, supra note 49, at EC 7-1.

53. George P. Fletcher, Two Modes of Legal Thought, 90 YALE L.J. 970, 973 (1981). 
is that lawyers are in a special position to argue that their own moral views contain the force of law. The clearest example of this is the Supreme Court, which can simply declare what the Constitution means. Supreme Court interpretations of the Constitution bind lawyers in the lower courts. But it is also true that, for all practical purposes, a lawyer's declaration of what the law is binds his clients, despite the reality that the lawyer's preexisting ideas of what is right may have informed her interpretation of the law. For this reason, it is probably best that lawyers' private economic interests, as well as their law school training, produce a certain amount of moral agnosticism, and cause them, as advocates, to interpret legal rules in ways favorable to their clients' interests.

\section{ConClusion}

From the moment students enter law school, a relentless, inexorable process of preference formation begins. Law students' preferences are shaped to mimic the institutional preferences of the legal community. The fate of a law student's human capital investment in legal training depends on the strength of society's demand for legal services. As demand for lawyers increases, the value of the law student's capital investment also rises.

Moreover, during law school, law students begin to view the legal process through the eyes of a lawyer: The value of the lawyer's role in society is emphasized, while its costs to society generally are ignored or heavily discounted. At best, these costs are obscured. Thus, the civic education that law students receive is one that emphasizes the positive role of the adversarial process, in which the very act of lawyering-regardless of the client or the cause-is an exercise in civic virtue.

The irony is that any effort made by law schools to mitigate this process threatens the quality of the educational process itself by undermining lawyers' ability to serve their clients most effectively. After all, if the lawyer on one side of the case views the matter solely from the perspective of her client, while opposing counsel sees both sides of the issue, the client represented by the lawyer with the broader perspective is likely to be disadvantaged. What then is the proper role for civic education in the American law school? In my view the most that we can hope for is that law students will recognize the gaming aspect of what they do as advocates. As teachers and students of the law, we should be taught that we are not about truth or justice, but advocacy. We should also be taught that values such as truth, justice, and virtue transcend the law.

All this is another way of saying that we should be taught simply not to take ourselves too seriously, and that we should not place too much trust in notions of civic virtue or civic education. The virtues of a civic education are vastly overstated. Unfortunately, civic education breeds homogeneity and discounts the virtues of diversity and dissent. If history has taught us nothing else, it is that the greatest civic virtues probably are a healthy mistrust of the state, coupled with a deep appreciation of the awful power of the 
state to do real evil. For example, Adrian Lyttelton has observed that a wide cross-section of the Italian population resisted the Nazis during the Holocaust because of a lack of civic virtue in Italian society:

Jewish survival would be hard to explain without taking into account certain features of Italian culture. The Italians did not trust the state. They showed an attitude of disobedience and skepticism toward the law and the duties of the citizen. They frequently acted at odds with their expressed beliefs, incurring the charge of cynicism. They lacked a true "civic culture" 54

Thus, as Lyttleton also explained, "[t]he Holocaust casts a dark light on previously received notions of civic virtue."55 Generally speaking, lawyers don't cause a great deal of harm. But on occasion our almost infinite capacity for self-justification and rationalization can lead to tremendous injustice. The amazing complicity of the French legal system during the Holocaust is perhaps the greatest testament to the inability of a legal system to distinguish between moral and legal positions. ${ }^{56} \mathrm{~A}$ healthy skepticism for the value of the law is perhaps the best defense against this sort of subversion. ${ }^{57}$

54. Adrian Lyttelton, La Forza del Destino, N.Y. REv. Books, Mar. 31, 1988, at 3, 8.

55. Id.

56. Richard H. Weisburg, Avoiding Central Realities: Narrative Terror and the Failure of French Culture Under the Occupation, 5 HuM. RTs. Q. 151, 161 (1983) (stating that "French law, and the executive and police authority, effectively outdid the Germans at their own racial game").

57. Other examples abound in the history of the twentieth century. The legal commitment to the principle of separate but equal facilities as a means of complying with the Equal Protection Clause of the Fourteenth Amendment, the anticommunism laws that persisted throughout the Cold War, and the Korematsu decision by the U.S. Supreme Court during World War II all are examples of the triumph of legal formalism over justice. 
HeinOnline -- 45 Stan. L. Rev. 1954 1992-1993 